\title{
Analisis Rasio Keuangan Terhadap Kinerja Perusahaan PT Eastparc Hotel, Tbk (Masa Awal Pandemi Covid-19)
}

\author{
Lily Rahmawati Harahap ${ }^{{ }^{*}}$, Rani Anggraini' ${ }^{2}$ Ellys $^{3}$, R.Y.Effendy ${ }^{4}$ \\ 1,2,3,4 Universitas IBA Palembang \\ harahaplily@gmail.com ${ }^{1}$, ranianggraini956@gmail.com ${ }^{2}$, \\ ellysthoyib@gmail.com ${ }^{3}$, effendyry@gmail.com ${ }^{4}$
}

\begin{abstract}
ABSTRAK
Penelitian ini bertujuan untuk mengetahui dan menjelaskan sejauhmana kinerja PT. Eastparc Hotel,Tbk terdampak dengan kemunculan pandemi Covid-19 di masa awal, sehingga dapat diketahui masalah yang dihadapi dan bagaimana cara mengatasinya. Sebagai populasi dalam penelitian ini adalah laporan keuangan tahun 2019 dan tahun 2020 dengan sampel berupa laporan keuangan periode 31 Desember 2019 hingga 31 Maret 2020. Laporan keuangan diperoleh dari data yang telah diterbitkan pada Bursa Efek Indonesia (BEI). Objek yang diteliti adalah PT Eastparc Hotel, Tbk. Untuk mengukur kinerja PT. Eastparc Hotel, Tbk, digunakan rasio keuangan yang terdiri dari rasio keuangan likuiditas, rasio keuangan solvabilitas, rasio keuangan aktifitas dan rasio keuangan profitabilitas. Hasil dari analisa yang dilakukan adalah: (1) pada periode masa awal pandemi covid-19, keadaan keuangan perusahaan adalah dalam keadaan yang baik jika ditinjau dari rasio likuiditas dan rasio solvabilitas; (2) sedangkan pada periode masa awal pandemi covid-19, keadaan keuangan perusahaan adalah dalam keadaan yang kurang baik jika ditinjau dari rasio aktifitas dan rasio profitabilitas.
\end{abstract}

Kata kunci: rasio keuangan; kinerja perusahaan.

\section{PENDAHULUAN}

Fenomena pandemi Covid-19 membuat dunia terhenyak akan perubahan masif yang terjadi, baik aktifitas kehidupan masyarakat mapun aktifitas ekonomi. Masyarakat dipaksa untuk beradaptasi dengan situasi yang terjadi, dimana kesehatan dan nyawa sebagai taruhannya. Virus yang terdeteksi pertama kali di kota Wuhan, China ini menularkan dengan media antar manusia melalui tetesan kecil (droplet), yang dikeluarkan dari hidung ataupun mulut ketika seseorang batuk maupun bersin. Mudahnya penularan tersebut menyebabkan cepatnya penyebaran kawasan yang terdampak serta banyaknya jumlah masyarakat yang tertular. Hal ini berujung kepada tingginya tingkat kematian. Dalam waktu relatif singkat, WHO mengumumkan bahwa penularan virus Covid-19 merupakan suatu pandemi. Pandemi adalah wabah yang berjangkit serempak dimana-mana meliputi daerah geografi yang luas (KBBI, 2020).

Untuk dapat memutus rantai penyebaran Covid-19, sebagian negara memilih menerapkan kebijakan memberlakukan karantina negara (lockdown), dan sebagian lagi (termasuk Indonesia) memilih melakukan kebijakan Pembatasan Sosial Berskala Besar (PSBB). Akibat yang timbul dari kebijakan-kebijakan tersebut adalah sangat terbatasnya ruang gerak dan mobilitas masyarakat, sehingga terjadi goncangan psikologis dan ekonomi (psychological and economic shock). Timbulnya ketakutan, kecemasan, stres dan kesepian merupakan gambaran dari goncangan psikologis yang dialami. Sedangkan 
goncangan ekonomi menyebabkan menurunnya kegiatan produksi, konsumsi dan operasi pada semua aspek.

Salah satu sektor yang terimbas keras akibat kebijakan tersebut adalah sektor perhotelan. Berdasarkan Peraturan Menteri Pariwisata dan Ekonomi Kreatif Nomor PM. 53/HM.001/MPEK/2013 tentang Standar Usaha Hotel, pengertian hotel adalah usaha penyediaan akomodasi berupa kamar-kamar di dalam suatu bangunan yang dapat dilengkapi dengan jasa pelayanan makan dan minum, kegiatan hiburan dan/atau fasilitas lainnya secara harian dengan tujuan memperoleh keuntungan. Berdasarkan Kamus Besar Bahasa Indonesia (2020) hotel adalah bangunan berkamar banyak yang disewakan sebagai tempat untuk menginap dan tempat makan orang yang sedang dalam perjalanan; bentuk akomodasi yang dikelola secara komersial, disediakan bagi setiap orang untuk memperoleh pelayanan, penginapan, makan dan minum.

Peraturan

mengharuskan masyarakat untuk tidak keluar rumah dan tidak berkumpul, dinonaktifkannya alat transportasi, kegiatan perkantoran, sekolah dan rumah ibadah, mengakibatkan aktifitas perhotelan mati suri. Jumlah hunian kamar hotel terjun ke titik terendah. Demikian juga yang dialami oleh PT Eastparc Hotel Tbk, yang bergerak di bidang jasa perhotelan, restoran, rumah minum dan event organizer. Penawaran umum perdana saham perusahaan telah dilakukan pada bulan Juni 2019. Terjadinya pandemi Covid-19 diduga mempengaruhi kinerja perusahaan, khususnya periode 31 Desember 2019 sampai dengan 31 Maret 2020.

KAJIAN PUSTAKA $\quad$ DAN
PENGEMBANGAN HIPOTESIS
Analisis Rasio Keuangan.

Bagi suatu perusahaan, menilai kinerja yang dilakukan adalah penting untuk memberikan informasi apakah perusahaan tersebut bekerja dengan seharusnya pada periode tertentu. Untuk mengukur kinerja perusahaan digunakan alat yang lazim yaitu rasio keuangan. Menuru Simamora (2000), rasio keuangan merupakan suatu dasar yang digunakan untuk mengevaluasi posisi dan pengelolaan keuangan perusahaan serta mengadakan perbandingan terhadap hasil dari tahun-tahun sebelumnya maupun mengadakan perbandingan dengan perusahaan-perusahaan lain. Selain itu, rasio keuangan juga merupakan suatu ukuran yang membandingkan dua pos tertentu pada neraca maupun laporan rugilaba baik secara individu atau kombinasi dari kedua laporan tersebut (Munawir, 2011).

Dengan hasil analisis yang diperoleh maka perusahaan dapat menjadikannya sebagai tolok ukur kesehatan perusahaan selama periode tertentu tersebut. Hal ini juga akan memudahkan pihak manajemen, para penanam modal, dan para kreditur untuk menganalisis kinerja bisnis, mengetahui kendala yang dihadapi dalam keuangan, yang pada akhirnya akan memudahkan dalam mengambil keputusan.

\section{Pengertian Analisis Rasio Keuangan}

Seperti yang telah dijelaskan, banyak pihak yang berkepentingan terhadap hasil dari suatu analisis rasio keuangan. Bagi manajemen digunakan untuk mengetahui tingkat kinerja perusahaan sehingga dapat dipilih evaluasi apa yang akan dilakukan. Bagi penanam modal digunakan untuk memutuskan apakah tepat melakukan investasi pada perusahaan yang dipilih. Sedangkan bagi kreditur digunakan sebagai pedoman layak tidaknya 
perusahaan tersebut memperoleh pinjaman yang dibutuhkan.

Sundjaja dan Inge (2003) menyebutkan bahwa analisis rasio keuangan adalah suatu metode perhitungan dan interpretasi rasio keuangan untuk menilai kinerja dan status perusahaan. Sedangkan menurut Sudana (2011) analisis rasio keuangan dilakukan untuk mengetahui kekuatan atau kelemahan perusahaan, dimana informasi ini penting bagi pihak manajemen untuk mengevaluasi kinerja yang dicapai dan untuk menyusun rencana perusahaan kedepannya.

Secara umum dapat dijelaskan bahwa untuk memaparkan posisi keuangan perusahaan digunakan analisis rasio keuangan sebagai alat. Atau dengan kata lain, proses untuk memantau dan mengamati indeks yang berkaitan dengan hasil yang terdapat pada laporan keuangan yang mencakup neraca, laporan rugi laba serta laporan arus kas disebut dengan analisis rasio keuangan. Proses ini bertujuan untuk untuk menilai kinerja perusahaan dari sisi keuangan.

Hasil atau prestasi atas fungsi pengelolaan aset perusahaan secara efektif selama periode tertentu yang telah dicapai oleh manajemen perusahaan menggambarkan kinerja keuangan (Rudianto, 2013). Sedangkan menurut Fahmi (2012), untuk menganalisis sejauh mana suatu perusahaan telah melaksanakan pengelolaan keuangan sesuai dengan aturan yang baik dan benar disebut dengan kinerja keuangan. Pengukuran kinerja keuangan dimaksudkan untuk mengetahui tingkat likuiditas, solvabilitas, profitabilitas dan stabilitas (Munawir, 2011).

\section{Jenis-Jenis Rasio Keuangan.}

Sebagai alat untuk tujuan analisis, rasio keuangan dapat dijelaskan terbagi 4 (empat), kelompok, yang mencakup rasio likuiditas, solvabilitas, profitabilitas, dan aktifitas. Syamsuddin (2009) menjelaskan bahwa data pada neraca dan laporan labarugi merupakan dasar untuk menghitung rasio hutang, data pada neraca merupakan dasar untuk menghitung rasio likuiditas, dan data pada neraca dan laporan laba-rugi merupakan dasar untuk menghitung rasio aktifitas dan profitabilitas.

\section{METODOLOGI PENELITIAN. Populasi dan Sampel}

Pendekatan deskriptif kuantitatif merupakan metode yang digunakan dalam penelitian ini dengan menggunakan data sekunder, yang diperoleh dari laman resmi BEI. Objek yang diteliti adalah PT Eastparc Hotel Tbk, yang bergerak di bidang jasa perhotelan, restoran, rumah minum dan event organizer. PT Eastparc Hotel Tbk, telah melakukan go public dengan penawaran umum saham pada tahun 2019 (http://eastparc.co.id/investment/detail/1, 2020). Instrumen yang digunakan pada penelitian ini berupa laporan keuangan bulan Desember 2019 dan bulan Maret 2020.

\section{Metode Analisis Data}

Sedangkan alat analisis yang digunakan adalah: a) rasio likuiditas, yang terdiri dari current ratio, quick ratio, cash ratio ; b) rasio solvabilitas, yang terdiri dari debt to total asset ratio, debt to equity ratio, long term debt to equity ratio, times interest earned; c) rasio profitabilitas, yang terdiri gross profit margin, net profit margin, return on investment, return on equity dan d) rasio aktifitas, yang terdiri dari receivable turnover, working capital turnover, fixed assets turnover, total assets turnover. 


\section{HASIL DAN PEMBAHASAN}

Hasil yang diperoleh dari pengolahan data laporan keuangan adalah:

Rasio likuiditas: menggambarkan kemampuan suatu perusahaan untuk memenuhi kewajibannya yang harus segera diselesaikan dengan menggunakan aktiva lancar yang dimiliki. Kewajiban tersebut baik berupa kewajiban eksternal maupun internal perusahaan.

$\begin{array}{ll}\text { Current Ratio } & =\frac{\text { Current Assets }}{\text { Current Liabilities }} \\ 31 \text { Desember } 2019 & =\frac{49.623 .449 .529}{31.175 .268 .205}=1,59 \\ 31 \text { Maret } 2020 & =\frac{45.289 .661 .903}{22.942 .640 .108}=1,97\end{array}$

Nilai current Ratio PT Eastparc Hotel Tbk pada 31 Maret 2020 meningkat sebesar 0,38 dari periode sebelumnya.

Quick Ratio $=\frac{\text { Current Assets-Inventory }}{\text { Current } \text { Liabilities }}$
31 Desember $2019=\frac{49.623 .449 .529-609.028 .951}{31.175 .268 .205}$
$=1,57$
31 Maret $2020=\frac{45.289 .661 .903-455.621 .427}{22.942 .640 .108}$
$=1,95$

Nilai Quick Ratio PT Eastparc Hotel Tbk pada 31 Maret 2020 meningkat sebesar 0,38 dari periode sebelumnya.

$$
\begin{aligned}
& \text { Cash Ratio }=\frac{\text { Cash or Cash Equivalent }}{\text { Current Liabilities }} \\
& 31 \text { Desember } 2019=\frac{8.526 .587 .587}{31.175 .268 .205}=0,27 \\
& 31 \text { Maret } 2020 \quad=\frac{2.944 .571 \cdot 282}{22.942 .640 .108}=0,12
\end{aligned}
$$

Nilai Cash Ratio PT Eastparc Hotel Tbk pada 31 Maret 2020 menurun sebesar 0,15 dari periode sebelumnya.

\section{Rasio Solvabilitas}

Rasio solvabilitas menggambarkan kewajiban perusahaan untuk memenuhi semua hutang yang dimilikinya dengan menggunakan seluruh aktiva apabila perusahaan tersebut dilikuidasi.

Debt to Total Asset Ratio $=\frac{\text { Total Debt }}{\text { Total } \text { Assets }}$

31 Desember $2019=\frac{53 \cdot 211 \cdot 905 \cdot 386}{306 \cdot 784 \cdot 059 \cdot 331}=0,173$

31 Maret 2020

$$
=\frac{44.416 .657 .535}{297.726 .668 .010}=0,149
$$

Nilai debt to total asset ratio PT Eastparc Hotel Tbk pada 31 Maret 2020 menurun sebesar 0,024 dari periode sebelumnya.

Debt to Equity Ratio $=\frac{\text { Total } \text { Debt }}{\text { Equity }}$
31 Desember $2019=\frac{53 \cdot 211.905 .386}{239.550 \cdot 214.792}=0,222$
31 Maret $2020 \quad=\frac{44.416 .657 .535}{239.936 .429 .525}=0,185$

Nilai debt to equity ratio PT Eastparc Hotel Tbk pada 31 Maret 2020 menurun sebesar 0,037 dari periode sebelumnya.

Long Term Debt to Equity Ratio $=$
$\frac{\text { Long Term Debt }}{\text { Equity }}$
31 Desember $2019=\frac{22.036 .637 .181}{239.550 .214 .792}=0,091$
31 Maret $2020 \quad=\frac{21.474 .017 .427}{239.936 .429 .525}=0,089$

Nilai long term debt to equity ratio PT Eastparc Hotel Tbk pada 31 Maret 2020 menurun sebesar 0,002 dari periode sebelumnya.

Times Interest Earned $=\frac{E B I T}{\text { Interest }}$

31 Desember $2019=\frac{1.820 \cdot 296.635}{1.786 .441 .329}=1,018$

31 Maret $2020 \quad=\frac{602 \cdot 339.279}{756 \cdot 299.951}=0,796$ 
Nilai times interest earned PT Eastparc Hotel Tbk pada 31 Maret 2020 menurun sebesar 0,222 dari periode sebelumnya.

\section{Rasio Aktivitas}

Rasio aktivitas menggambarkan ukuran efektifitas perusahaan dalam menggunakan aktiva yang dimiliki.

Receivable Turn Over $=\frac{\text { Penjualan }}{\text { Piutang }}$

31 Desember $2019=\frac{14 \cdot 299 \cdot 806 \cdot 910}{2 \cdot 406 \cdot 813.879}=5,94$

31 Maret $2020 \quad=\frac{13.882 .099 .291}{3 \cdot 139.914 .693}=4,42$

Nilai receivable turn over PT Eastparc Hotel Tbk pada 31 Maret 2020 menurun sebesar 1,52 dari periode sebelumnya.

Working Capital Turn Over $=\frac{\text { Penjualan }}{\text { Modal Kerja }}$

31 Desember $2019=\frac{14 \cdot 299 \cdot 806 \cdot 910}{18.448 \cdot 181 \cdot 324}=0,77$

31 Maret $2020 \quad=\frac{13 \cdot 882 \cdot 099 \cdot 291}{22 \cdot 347 \cdot 021 \cdot 795}=0,62$

Nilai working capital turn over PT Eastparc Hotel Tbk pada 31 Maret 2020 menurun sebesar 0,15 dari periode sebelumnya.

Fixed Assets Turn Over $=\frac{\text { Penjualan }}{\text { Total Aktiva Tetap }}$

31 Desember $2019=\frac{14 \cdot 299 \cdot 806 \cdot 910}{257 \cdot 160 \cdot 609 \cdot 801}=0,05$

31 Maret $2020 \quad=\frac{13 \cdot 882 \cdot 099 \cdot 291}{252.437 \cdot 006 \cdot 107}=0,05$

Nilai fixed assets turn over PT Eastparc Hotel Tbk pada 31 Maret 2020 tidak mengalami perubahan dari periode sebelumnya.

Total Assets Turn Over $\quad=\frac{\text { Penjualan }}{\text { Total Aktiva }}$

31 Desember $2019=\frac{14 \cdot 299 \cdot 806 \cdot 910}{306 \cdot 784.059 .331}=0,04$

31 Maret $2020 \quad=\frac{13 \cdot 882 \cdot 099 \cdot 291}{297 \cdot 726 \cdot 668.010}=0,04$

Nilai total assets turn over PT Eastparc Hotel Tbk pada 31 Maret 2020 tidak mengalami perubahan dari periode sebelumnya.

\section{Rasio Profitabilitas}

Rasio profitabilitas menggambarkan sejauh mana suatu perusahaan mampu mencari keuntungan dalam menjalankan kegiatan perusahaan. Rasio profitabilitas juga memberikan suatu ukuran sejauh mana tingkat efektifitas manajemen suatu perusahaan.

Gross Profit Margin $=\frac{\text { Laba Kotor }}{\text { Penjualan }}$

31 Desember $2019=\frac{8 \cdot 629 \cdot 979.951}{14 \cdot 299 \cdot 806.910}=0,60$

31 Maret $2020 \quad=\frac{8 \cdot 217 \cdot 266 \cdot 538}{13 \cdot 882 \cdot 099 \cdot 291}=0,59$

Nilai gross profit margin PT Eastparc Hotel Tbk pada 31 Maret 2020 menurun sebesar 0,01 dari periode sebelumnya.

Net Profit Margin =

Earning After Interest and Tax Penjualan

31 Desember $2019=\frac{1.986 .094 .843}{14.299 .806 .910}=0,13$

31 Maret $2020 \quad=\frac{687.144 .882}{13 \cdot 882 \cdot 099.291}=0,04$

Nilai net profit margin PT Eastparc Hotel Tbk pada 31 Maret 2020 menurun sebesar 0,09 dari periode sebelumnya.

$\begin{aligned} & \text { Return On Investment }= \\ & \text { Earning After Interest and Tax } \\ & \text { Total Assets }\end{aligned}$
31 Desember $2019=\frac{1.986 .094 .843}{306.784 .059 .331}=0,006$
31 Maret $2020 \quad=\frac{687.144 .882}{297.726 .668 .010}=0,002$

Nilai return on investment PT Eastparc Hotel Tbk pada 31 Maret 2020 menurun sebesar sebesar 0,004 dari periode sebelumnya.

$\begin{aligned} & \text { Return On Equity }= \\ & \text { Earning After Interest and Tax } \\ & \text { Equity }\end{aligned}$
31 Desember $2019=\frac{1.986 .094 .843}{239.550 .214 .792}=0,008$
31 Maret $2020=\frac{687.144 .882}{239.936 .429 .525}=0.002$


Nilai return on equity PT Eastparc Hotel Tbk pada 31 Maret 2020 menurun sebesar sebesar 0,006 dari periode sebelumnya.

\section{KESIMPULAN}

Berdasarkan analisis dan pembahasan rasio keuangan PT Eastparc Hotel Tbk selama periode 3 (tiga) bulan yang berakhir pada tanggal 31 Desember 2019 dan 31 Maret 2020, beberapa simpulan yang dapat dipaparkan adalah pertama, dari segi likuiditas, keuangan PT Eastparc Hotel Tbk menunjukkan keadaan yang baik. PT Eastparc Hotel Tbk memiliki kemampuan untuk memenuhi kewajibannya yang segera jatuh tempo dengan menggunakan aktiva yang dimiliki perusahaan. Kedua, Dari segi solvabilitas, keuangan PT Eastparc Hotel Tbk menunjukkan keadaan yang baik. Pada periode 31 Maret 2020 perusahaan berhasil mengurangi pembiayaan asset dari hutang dalam kegiatan operasional perusahaan. Ketiga, Dari segi rasio aktifitas, keuangan PT Eastparc Hotel Tbk menunjukkan keadaan yang kurang baik karena adanya kenaikan piutang pada periode 31 Maret 2020. Sedangkan perputaran aktiva pada periode 31 Desember 2019 dan periode 31 Maret 2020 tidak ada mengalami kenaikan. Keempat, Dari segi profitabilitas, keuangan PT Eastparc Hotel Tbk menunjukkan keadaan yang kurang baik. Pada periode 31 Maret 2020 Eastparc Hotel Tbk kurang mampu mempertahankan tingkat keuntungan perusahaan dengan menurunnya laba yang cukup signifikan dari periode 31 Desember 2019. Dari hasil analisis dan simpulan, beberapa saran yang dapat ditawarkan kepada PT Eastparc Hotel Tbk adalah sebagai berikut pertama, dengan tingkat likuiditas dan solvabilitas yang baik, PT Eastparc Hotel Tbk dianggap mampu untuk melakukan operasional usaha. diharapkan kegiatan operasional disesuaikan dengan keadaan sehingga dapat mempertahankan kedua rasio tersebut. Kedua, dengan tingkat aktifitas dan profitabilitas yang kurang baik, maka PT Eastparc Hotel Tbk diharapkan masih mampu menggunakan asset yang ada untuk menopang operasional usaha. Ketiga, diharapkan perusahaan mampu meningkatkan pemberdayaan sumber daya yang ada, baik secara efektif maupun efisien dalam rangka menghadapi kondisi pandemi Covid-19. Dan keempat, Manajemen perusahaan diharapkan dapat melakukan perubahan operasional serta mencari ide baru untuk dapat tetap mempertahankan usaha dengan keadaan pandemi Covid-19.

\section{DAFTAR PUSTAKA}

Fahmi, I. 2012. Analisis Kinerja Keuangan. Bandung: Alfabeta

IDX. 2020. Ikhtisar Pasar. Tersedia: https://www.idx.co.id. Diakses: November 2020

Kasmir. 2016. Analisis Laporan Keuangan. Jakarta: RajaGrafindo Persada

KBBI. 2020. Pandemi. Kamus versi online/daring (dalam jaringan). Tersedia: https://www.kbbi.web.id/pandemi. Diakses: Juni 2020.

Munawir, S.2011. Analisis Laporan Keuangan. Edisi Keempat. Yogyakarta: Liberty

PT.Eastparc Hotel. (2020). Buku Prospektus. Daring: $\quad 15 / 11 / 20$. Tersedia: http://eastparc.co.id/images/investation/ dXTYtMjz6dOxaV4VPlr1Hd5pO06QN XDL6DWecz3Y.pdf

Rudianto. 2013. Akuntansi Manajemen. Jakarta; Erlangga.

Simamora, H. 2000. Akuntansi: Basis Pengambilan Keputusan. Jilid Dua, Cetakan Pertama. Jakarta: Salemba Empat 
Sudana, I.M . 2011. Manajemen Keuangan Perusahaan Teori dan Praktik. Jakarta: Erlangga.

Sundjaja, R.S. dan Inge, B. 2003. Manajemen Keuangan Satu. Jakarta: Literata Lintas Media.

Syamsuddin, L. 2009. Manajemen Keuangan Perusahaan. Jakarta: Rajawali Pers. 